Swarthmore College

Works

$10-1-1990$

\title{
Postrevolutionary Mobilization In China: The One-Child Policy Reconsidered
}

Tyrene White

Swarthmore College, twhite1@swarthmore.edu

Follow this and additional works at: https://works.swarthmore.edu/fac-poli-sci

Part of the Political Science Commons

Let us know how access to these works benefits you

\section{Recommended Citation}

Tyrene White. (1990). "Postrevolutionary Mobilization In China: The One-Child Policy Reconsidered". World Politics. Volume 43, Issue 1. 53-76. DOI: 10.2307/2010551

https://works.swarthmore.edu/fac-poli-sci/95

This work is brought to you for free by Swarthmore College Libraries' Works. It has been accepted for inclusion in Political Science Faculty Works by an authorized administrator of Works. For more information, please contact myworks@swarthmore.edu. 


\section{POSTREVOLUTIONARY \\ MOBILIZATION IN CHINA \\ The One-Child Policy Reconsidered}

By TYRENE WHITE*

$\mathrm{D}$ URING the ig8os, the study of Chinese politics was dominated by the premise that the death of Mao and the rise of Deng Xiaoping marked the beginning of a new political epoch. Some scholars argued that the political course set in motion at the famous Third Plenum of the Eleventh Central Committee of December r 978 signaled a fundamental, even revolutionary break with the past; others saw a slower drift from a monistic system toward a more consultative authoritarianism. ${ }^{1}$ Either way, the deradicalized, demobilizational thrust of the post-Mao reforms appeared to augur China's transition to a "postrevolutionary phase" of political normalization, regularized decision making and institutionalized party rule. ${ }^{2}$ Against that background, China's "one-child-per-couple" family planning policy, introduced in I979, appeared to run counter to the post-Mao political premise. With its radical goal, collectivist values, and mobilizational flavor, the one-child policy bore many of the characteristics of a Maoist-era mass mobilization campaign.

To account for this contrast, some scholars considered the one-child policy to be an isolated exception to the demobilizational trend; they argued that the specter of a looming population crisis that would under-

* An earlier version of this paper was presented at the 4 ist Annual Meeting of the Association for Asian Studies, Washington, DC, March 17-19, I989. The research presented here was supported by the Swarthmore College Faculty Research Support Fund; the preparation of this manuscript was made possible by a sabbatical from Swarthmore College and a postdoctoral fellowship from the Fairbank Center for East Asian Research, Harvard University. Special thanks to Jean Oi, James Kurth, and Kenneth Sharpe for their comments on earlier drafts. Any errors or deficiencies that remain are mine alone.

'Lowell Dittmer, China's Continuous Revolution: The Post-Liberation Epoch, 1949-198I (Berkeley: University of California Press, 1987); Harry Harding, "Political Development in Post-Mao China," in A. Doak Barnett and Ralph N. Clough, eds., Modernizing China: PostMao Reform and Development (Boulder, CO: Westview Press, 1986), 13-37; Harry Harding, China's Second Revolution: Reform after Mao (Washington, DC: Brookings, I987); Tang Tsou, "Back from the Brink of Revolutionary-Feudal Totalitarianism," in Victor Nee and David Mozingo, eds., State and Society in Contemporary China (Ithaca, NY, and London: Cornell University Press, I983), 53-88.

${ }^{2}$ Richard Lowenthal, "The Post-Revolutionary Phase in China and Russia," Studies in Comparative Communism I6 (Autumn 1983), I9I-20 I; Dittmer (fn. I), I I. 
cut the modernization goals of the new elite left no alternative to a strict birth control program. ${ }^{3}$ Others, however, assumed that, all reformist statements and policies notwithstanding, the one-child campaign was revelatory - that is, evidence of a mobilization regime at its intrusive, penetrative worst. ${ }^{4}$ Still others maintained that the enduring mobilizational impulse revealed by the one-child campaign was an artifact of the previous revolutionary epoch that would slowly disappear during the transition to institutionalized party rule. 5 What these views had in common was their implicit reference to an underlying model of Leninist regimes, one in which mobilization cannot outlive the transition to postrevolutionary communism. This model was most fully elaborated by Richard Lowenthal, who argued that, as modernization proceeds, the political attributes of the revolutionary phase-personalized, charismatic rule, revolutionary class struggle, and mass mobilization in pursuit of radical political and economic goals-inevitably give way to the postrevolutionary politics of oligarchic rule, regularized decision making, and party institutionalization. ${ }^{6}$

The Lowenthal model has drawn criticism on many counts, 7 but the hypothesis that postrevolutionary regimes eventually lose the capacity and desire to use mobilizational means has met no serious challenge. Kenneth Jowitt, for example, warned against interpreting the transition as a smooth and unilinear one. He argued that the difficult process of transition from revolutionary consolidation to postrevolutionary ruleor in his words, from the task of mobilization to the task of "inclusion"-frequently triggers mobilizational responses from threatened party elites. He also rejected the notion of a strict dichotomy between the mobilization and postmobilization phases, arguing for the existence of "amalgam-regimes" that represent "fragile combinations" of the two. Stressing that coexistence did not imply compatibility, however, he con-

3 Martin King Whyte, "Who Hates Bureaucracy? A Chinese Puzzle," in Victor Nee and David Stark, eds., Remaking the Economic Institutions of Socialism: China and Eastern Europe (Stanford, CA: Stanford University Press, 1989), 233-54; Joyce K. Kallgren, "Politics, Welfare, and Change: The Single-Child Family in China," in Elizabeth J. Perry and Christine Wong, eds., The Political Economy of Reform in Post-Mao China (Council on East Asian Studies, Harvard University, I985), I 3 I-56.

${ }^{4}$ Steven W. Mosher, Broken Earth: The Rural Chinese (New York: Free Press, 1983).

${ }^{5}$ Harding (fn. I, I986).

${ }^{6}$ Richard Lowenthal, "Development vs. Utopia in Communist Politics," in Chalmers Johnson, ed., Change in Communist Systems (Stanford, CA: Stanford University Press, i 970), 33-1 16; Lowenthal (fn. 2).

7 For a cogent review of these critiques, see David Stark and Victor Nee, "Toward an Institutional Analysis of State Socialism," in Nee and Stark (fn. 3), I-3I. See also Constance Squires Meany, "Is the Soviet Present in China's Future?" World Politics 39 (January 1987), 203-30; Kenneth Jowitt, "Inclusion and Mobilization in European Leninist Regimes," World Politics 28 (October 1975), 69-96. 
curred with Lowenthal on the fundamental conflict between mobilizational and postmobilizational methods of political rule, describing the two methods as stark opposites. According to Jowitt, mobilization is characterized by the "controlled or elite-directed disruption" of "social, personal, institutional, and psychological" routines, as opposed to "the methodical consideration and management of tasks" characteristic of postrevolutionary rule. ${ }^{8}$

Do these propositions fit the Chinese case? The brutal crackdown on the 1989 democracy movement was a perfect illustration of Jowitt's "threat-reaction" model of elite response to a regime-threatening crisis. In this essay, however, I will argue that mobilization has remained an integral, active part of the postrevolutionary Chinese political process, not merely a reactive tool of fearful conservatives. Using the one-child campaign as a case study, I will demonstrate that the instrument of mobilization in Chinese politics, the mass campaign, was inherited by Deng Xiaoping as a part of the institutional legacy of the Maoist regime. Despite their unambiguous repudiation of Maoist campaign methods in I 978, the post-Mao reformers sought to harness them in practice for their own purposes, transforming an instrument of calculated disruption into an instrument of methodical, engineered change. As a result, the form, content, and intensity of the campaign changed over the course of the decade, but mobilization remained an essential instrument of communist party rule, particularly in the countryside.

\section{Mobilization after Mao}

One of the defining characteristics of the Maoist era in Chinese politics (1949-1976) was the continual use of "mass mobilization campaigns" (qunzhong yundong) to achieve socialist goals. Although mobilizational methods were a standard tool of political organization in other Leninist regimes, the Chinese campaigns were distinctive for the "utter seriousness" with which political study and ideological transformation were pursued. ${ }^{9}$ For Mao, revolutionary goals were primary; under his leadership, China's revolutionary politics oscillated between two types of intensive mass participation and political struggle. The first was "storming," the distinctively Maoist model of mobilization from below, in which the

\footnotetext{
${ }^{8}$ Ibid., 93 and 94-95. Jowitt's challenge goes far toward acknowledging a continuing role for mobilization in postrevolutionary regimes, but whereas he views the continued use of mobilization to be negative or reactive, a "response to the problems and challenges" of expanding the bases of regime support, I view it as a positive instrument of power.

9 Andrew Walder, Communist Neo-Traditionalism: Work and Authority in Chinese Industry (Berkeley: University of California Press, I986), I2 I.
} 
elite party membership is subjected to rectification by the nonelite masses. The second was "engineering," the Maoist-Liuist-Leninist model of party-controlled mobilization from above in pursuit of specific and practical goals. ${ }^{\circ}$

Campaigns served at least three vital functions during the Maoist era. First, they helped the party transcend its own organizational limits by recruiting and leading mass participants in a wide variety of taskseverything from implementing new marriage laws, to disease control, to eliminating counterrevolutionaries. ${ }^{\text {" }}$ This function was particularly important during the I950s, when mass involvement was needed to reinforce the party's administrative capacities and to indoctrinate and mobilize a newly liberated population. Second, campaigns were tools for correcting various bureaucratic and political ills. They were used to rectify the party, promote discipline and unity, purify the state bureaucracy, and prevent the entrenchment of elite-mass cleavages. Third, campaigns were used as populist instruments of permanent revolution to "smash" the party/state apparatus. ${ }^{12}$

The post-Mao leadership formally repudiated all three functions of the mass campaign. Mao's culminating effort at smashing the party/state during the Cultural Revolution had such force and consequence that the post-Mao elite, victims of the process, formally abandoned mobilizational politics and fostered the process of institution building. ${ }^{13}$ The new leaders replaced mass campaigns and permanent revolution with routinization and modernization as the primary means and ends of state power in post-Mao China. Radicalism gave way to "systems engineering," with all its attendant overtones of incremental manipulation of countless social, political, and economic levers. And populist, revolutionary methods of mass participation gave way to imperfect electoral mechanisms, expanded public debates and channels for political expression and influence, glorification of the rule of law, and a shrinking monopoly of party power. In short, the post-Mao elite fundamentally redefined its historical mission, abandoning the rapid achievement of revolutionary ends by means of class struggle in favor of the steady development of the "primary stage of socialism" and the construction of a "socialist spiritual civ-

\footnotetext{
${ }^{10}$ Dittmer (fn. I), 6. For other discussions of mobilization, see Squires Meany (fn. 7), and Walder (fn. 9), i I 3-22.

"Charles P. Cell, Revolution at Work: Mobilization Campaigns in China (New York: Academic Press, 1977), 106-7.

${ }^{12}$ Harry Harding, Organizing China: The Problem of Bureaucracy, 1949-1976 (Stanford: Stanford University Press, I98I), 33 I-33; Dittmer (fn. I), 6-8.

${ }^{13}$ Squires Meany (fn. 7); Tang Tsou (fn. I).
} 
ilization." ${ }_{14}$ In so doing, the elite brought the Maoist revolutionary phase to an end.

The question is whether the end of the revolutionary phase meant the end of party-led mobilization, as was the case in the Soviet Union. ${ }^{15}$ Despite the formal repudiation of mass movements, only the third type of mobilization campaign disappeared entirely in the I980s. Mobilization was still employed to achieve political goals, such as party rectification (I983-I986), eliminating spiritual pollution (I983), and countering bourgeois liberalization ( 1987 and I989). It was also used to achieve substantive goals, such as obligatory tree planting, electoral reform, and controlling economic crime. ${ }^{16}$ Nowhere has the use of mobilization been more sustained or controversial, however, than in the arena of family planning.

\section{A. The "One-Child-per-Couple" Mobilization}

\section{Campaign, I979-ig83}

The effort to limit couples to only one child began just as China's new leadership was repudiating Maoist campaign methods. There is no shared, unambiguous definition of a mass campaign or its precise form, but the family planning campaign implemented between 1979 and 1983 fulfilled and exceeded every basic requirement. Two studies of campaigns and their dynamics, Gordon Bennett's Yundong and Charles Cell's Revolution at Work, provide working definitions. Bennett defined the campaign as "a government-sponsored effort to storm and eventually overwhelm strong but vulnerable barriers to the progress of socialism through intensive mass mobilization of active personal commitment." ${ }_{17}$ Cell relied on the definition provided by a 1959 article in Hongqi (Red Flag), which described the campaign as an "organized mobilization of collective action aimed at transforming thought patterns, class/power relationships and/or economic institutions and productivity." More simply, he noted that "all campaigns involve an increased intensity of activity

${ }^{14}$ Zhao Ziyang, "Advance Along the Road of Socialism with Chinese Characteristics," Beijing Review 45, November 9-15, I987, pp. I-XXVII.

${ }^{15}$ In the Chinese case, the communique of the Third Plenum of the Eleventh Central Committee in December 1978 and the resolution on CCP history adopted in June 198 I marked the end of the revolutionary phase. The parallel moment in Soviet history was the party program adopted at the 22nd Party Congress in October 196r. On the Soviet case, see Lowenthal (fn. 2).

${ }^{16}$ Lester Ross, "Obligatory Tree Planting: The Role of Campaigns in Policy Implementation in Post-Mao China," and Barrett L. McCormick, "Leninist Implementation: The Election Campaign," both in David M. Lampton, ed., Policy Implementation in Post-Mao China (Berkeley: University of California Press, 1987), 225-52 and 383-41 3.

${ }_{17}$ Gordon A. Bennett, Yundong: Mass Campaigns in Chinese Communist Leadership (Berkeley, CA: Center for Chinese Studies, 1976), i 8. 
beyond what is expected in regular work and living routines"; "what may not start out as a campaign may in due course become one, or vice versa." 18

Both definitions suggest two irreducible characteristics of the mass campaign. First, its substantive goal is to advance socialism by targeting a particular obstacle and/or by promoting a particular ideal. Second, the procedural requirements for a mass campaign are that it be organized and launched from above, led by the party and mass organizations, and that the masses be mobilized beyond their normal routines. The onechild campaign met all of these criteria.

First, with the immediate task of building socialism redefined to be the achievement of the four modernizations, promoting the policy of one child per couple not only explicitly aided economic goals; it also targeted old habits and customs that had been variously described as decadent or feudal, and that stood as barriers to socialist development. For example, such traditional sayings as "men are superior to women" and "the more children, the more happiness" became objects of condemnation in propaganda campaigns, as did the associated behavior of female infanticide. ${ }^{19}$ The policy of promoting only one child per couple and denouncing the traditional preference for sons was tantamount to launching a narrowly defined cultural revolution.

Second, beginning in 1979 , the call for the one-child family led to nationwide mobilization. Hua Guofeng set forth the impossible goal of reducing the population growth rate to five per thousand by 1985 ; Chen Muhua, head of the State Council Leading Group for Family Planning, called for a mass campaign to achieve this target. ${ }^{20}$ Provincial leaders responded by holding mobilization meetings attended by representatives of all party, government, and mass organizations; recruiting family planning activists and propagandists from various units; sending medical and propaganda teams into the countryside to promote birth control; and publishing articles glorifying the one-child family. ${ }^{21}$

Subsequently, implementation of the one-child program involved the use of standard campaign methods. Both Bennett and Cell listed specific

${ }^{18}$ Cell (fn. I I), 7 .

${ }^{19}$ Foreign Broadcast Information Service, Daily Report-China [hereafter cited as FBIS], February 15, 1980, p. Li4; Renmin Ribao, September 25, i980, p. I.

${ }^{20}$ FBIS (Supplement No. 15), July 2, 1979, p. 19; Sichuan Provincial Service, December I 7 , 1979, in FBIS, December 18, 1979, p. Q3; Li Xiuzhen, "Dangqian jihua shengyu gongzuode xingshi he renwu" [The current situation and tasks in family planning work], Renkou Yanjiu I ( 1980$)$, 3 .

${ }_{21}$ Tyrene White, "Population Policy and Rural Reform in China, I977-1984: Policy Implementation and Interdependency at the Local Level" (Ph.D. diss., Ohio State University, I985), chap. 3 . 
indicators of campaign activity, with Cell providing the most exhaustive list. ${ }^{22}$ Three types of indicators emerge from his classification: first, informational indicators (newspaper articles, slogans, mobilization meetings, targets for criticism, stories for emulation, pamphlets, signs, banners, exhibits); second, organizational indicators (sending in outside cadres, creating work teams, reallocation of resources, curtailment of other programs or activities, disruption of work routines or reorganization of the unit); third, mass participation indicators (letter writing; participating after regular work hours; mobilization of minority, youth, or other special groups and organizations; study groups; struggle and/or criticism sessions; local, regional and national rallies).

Virtually all of the above tools were used between 1979 and 1984 to implement the one-child policy. ${ }^{23}$ Telephone conferences and mobilization meetings were employed to energize cadres and to disseminate campaign targets. Special medical teams were sent to perform sterilizations and abortions, or to insert intrauterine devices. Propagandists filled newspapers with model stories and educational editorials, and cadres who violated the new policy were used as negative models for public discussion. In rural areas, where the greatest resistance was encountered, local party cadres held as many as nine or ten mobilization meetings per year in one locality. ${ }^{24}$ Normative and material incentives, such as glorification meetings and cash rewards, were used to encourage compliance. Those who resisted, however, encountered coercive measures. In the most extreme cases, women were forcibly taken to clinics for abortions or other procedures; more typical, however, was the practice of making women attend endless meetings without pay, or subjecting couples to propaganda and harassment in their homes. ${ }^{25}$

Although the struggle sessions against offenders did not take on the intensity of those against political targets during the Maoist period, individuals, and wayward cadres in particular, were isolated and criticized publicly as examples. Their punishment frequently went beyond eco-

${ }^{22}$ Bennett (fn. I 7 ), 38-74; Cell (fn. i I), 92-I io.

${ }^{23}$ The primary literature on this period is vast. For analyses and descriptions, see Tyrene White, "Implementing the 'One-Child-per-Couple' Population Program in Rural China: National Goals and Local Politics," in Lampton, ed. (fn. I6), 284-31 7; Mosher (fn. 4), 2246I; John S. Aird, "Coercion in Family Planning: Causes, Methods and Consequences," in U.S. Congress, Joint Economic Committee, China's Economy Looks toward the Year 20oo, vol. I, The Four Modernizations (Washington, DC: Government Printing Office, 1986), I 84-22 I.

${ }^{24}$ Yuan Fang and Gu Shengzu, "Nongye shengchan zerenzhi qianhoude jihua shengyu guanli tizhide bijiao fenxi" [A comparative analysis of the managerial system of family planning work before and after the agricultural responsibility system], Shehuixue yu shehui diaocha $2(1987), 7-16$.

${ }_{25}$ On these practices, see Aird (fn. 23) and Mosher (fn. 4). 
nomic sanctions, even to the point of obligatory sterilization. ${ }^{26}$ Conversely, cadre mobilization and emulation efforts were taken very seriously. In one Hubei village, the local "women's leader" (a female cadre in charge of women's affairs and family planning in each of China's production brigades and teams) attributed her brigade's exemplary record on birth control to the example set by the local cadres. She and the brigade's eight team-level women's leaders had undergone "voluntary" sterilizations when the one-child campaign began. ${ }^{27}$ Thus did they demonstrate their willingness to "take the lead" in family planning and set a good example for the masses.

In short, though the scope of the family planning campaign did not rival the radical political campaigns of the Maoist era, it was a classic mobilization drive of major proportions. Over time, however, pressures to bring campaign tactics in line with the requirements of an ongoing process of rural reform gave rise to a variant form of mobilization politics.

\section{B. The Politics of Institutionalized Mobilization, i $984-1989$}

Although mobilization for family planning was continuous in the early i 980 s, the environment for implementing the one-child policy had changed dramatically by the end of the Sixth Five-Year Plan in i985. At the time the campaign was launched in 1979, the regime of Hua Guofeng was fostering a mobilizational style of politics that had direct antecedents in the Maoist era. By the end of that year, however, political campaigns had been rejected as tools of policy implementation, and the reform coalition of Deng Xiaoping was rapidly consolidating power. As a result, the traditional language of mass mobilization was softened even while the demand for a one-child norm became more insistent.

By September 1980 , cadres were exhorted not to rely on coercion to enforce the policy; they were told to make family planning a part of their routine work. The one-child campaign continued, however, with the Central Committee and the Communist Youth League issuing an unprecedented "Open Letter" to all party and youth league members urging them to "take the lead" in having only one child..$^{28}$ In the cities, effective enforcement was made possible by the close surveillance of

${ }^{26}$ Beijing City Service, April 12, 1980, in FBIS, April 21, 1980, p. R 1; Renmin Ribao, April I I, I980, p. 4 ; Kyodo, June 26, 1980, in FBIS, June 27 , I980, p. Q I.

${ }_{27}$ Interview file, by the author, May 23, I982, Huashan commune. This interview was conducted as part of two periods of rural fieldwork in China (February-December 1982 and September 1983-June 1984). The commune (now reclassified a rural town) is situated to the northeast of Wuhan municipality, Hubei Province. Additional information on the field site and interview procedures may be found in White (fn. $2 \mathrm{I}$ ).

${ }^{28}$ Renmin Ribao, September 25, I980, p. I. 
women in the workplace and in neighborhoods, but rural enforcement posed enormous obstacles. Not only did the peasants strongly resist the one-child limit, but the pattern of rural organization underwent radical changes between 1980 and 1983 as the defining institutions of the Maoist era were dismantled. Household farming on collectively owned land replaced collectivized agriculture, separate organs of township government and economic management supplanted the people's commune, and the revival of free markets broke the party's absolute grip on rural income.

These structural changes diminished the political and economic power of rural cadres and substantially reduced the dependency and vulnerability of the peasantry. The changes also weakened a vital component of the local enforcement structure for family planning-grassroots women's leaders in production brigades and teams. ${ }^{29}$ As local activists, these women had provided the crucial link between the party hierarchy and rural women of child-bearing age by monitoring pregnancies and "mobilizing" for compliance; they now found that the political rewards of cadre service did not outweigh the material rewards of household production. Like other laborers, they were allotted plots of land and were obliged to fulfill their household responsibility contracts. At the same time, pressures to reduce the number of "nonproductive" cadres deprived them of the small administrative subsidy once provided by the brigade. Finally, in the altered political climate of the i 980 , women's leaders found themselves not just deprived of the status once implied in cadre service, but in danger of assault or abuse for their role in the family planning campaign. $3^{\circ}$

Although the situation stabilized by 1984 , these changes provoked a sense of panic about family planning work during 1982 and 1983 , as officials feared that grassroots organizational disarray or paralysis was undercutting the one-child campaign. To compensate for rising birth rates and organizational deficiencies, a sterilization campaign had been launched in late 1982 that continued sporadically through 1983 and 1984 . It was specifically directed at couples who were under the age of forty and already had two or more children, and it was designed to reduce the incidence of third or additional births. ${ }^{31}$ The full dimensions of the mo-

29 White (fn. 23).

$3^{\circ}$ One report from a county in Jiangsu Province indicated that there had been $38 \mathrm{I}$ "incidents of revenge" in twelve towns and townships in an eighteen-month period, of which 32 percent were related to family planning. See Su Suining, "There Are Many Causes of Strained Relations between Cadres and Masses in the Rural Areas," Nongmin Ribao, September 26 , 1988 , p. I, in $F B I S$, October 7, 1988, p. 13.

${ }^{31}$ Xinhua, November 1, 1982, in FBIS, November 3, 1982, p. K20; Qian Xinzhong, "Nuli kaichuang jihua shengyu xuanchuan jiaoyu gongzuo xin jumian" [Make great efforts to initiate the new phase of family planning propaganda and education work], Renkouxue Kan 
bilization remain unclear, but by the end of February 1983 , nearly nine million "birth control operations" had been performed nationally, a figure r.6 times the total for all of $1982 . .^{32}$ In Hubei Province alone, one million sterilizations occurred over the course of 1983.33

By the end of 1983 , other elite priorities began to overtake the onechild campaign. A party rectification campaign was launched, a central feature of which was to correct the bad "work style" of many party members and to improve party-mass relations. In addition, the reformers were poised to push through new rural reforms at the end of 1983 that would commercialize the rural economy and break up the party's monopoly of supply and distribution. At the same time, the township governments that had replaced people's communes were placed on a tighter fiscal leash, with expenditures for basic activities like family planning set in an annual fixed budget. In this shifting political, economic, and institutional context, a new central document on family planning was issued in I 984 . Central Document 7 departed from its predecessors by allowing some restricted exceptions to the one-child limit, exceptions that applied to about 5 percent of all couples of child-bearing age among the majority Han population (rules for minorities were slightly less strict). More importantly, the document repudiated the use of coercion to enforce the one-child limit, stressing instead the need for routine and patient work in order to gain compliance. ${ }^{34}$ Subsequently, family planning was declared to be a fundamental state policy: the government stressed the obligation of Chinese citizens to engage in family planning, and made efforts to build an organizational structure for routine administration. Yet the gap between official family planning targets and the capacity of the formal party/state apparatus to reach them undermined efforts to regularize grassroots implementation. Instead, the implementation process settled unstably into a pattern of institutionalized mobilization.

Institutionalized mobilization is a variant form of implementation, which involves periodic, functionally defined mobilization efforts that ( $\mathrm{I}$ ) temporarily intensify coercive and normative incentives; (2) vary from region to region in timing, intensity, and scope; (3) last for limited, predictable periods of time (often specified at the outset); $(4)$ have as their

\footnotetext{
I (1983), 9; Xinhua, January 10, 1983, in FBIS, January 13, 1983, pp. K13-14; Beijing Domestic Service, January 27, I983, in FBIS, March 3, 1983, p. K I i; Shi Chengli, "Wo guo jihua shengyu gongzuode fenqi" [Analysis of our country's family planning work], Xibei Renkou I (I988), 3I; interview conducted by the author, June 8, I984, Family Planning Commission, Hubei Province.

${ }^{32}$ Shi (fn. 3I), 3 I.

33 Interview (fn. 3I).

${ }^{34}$ Jihua Shengyu Ban, Jiankang Bao, March 9, 1984.
} 
primary goal behavioral control or "practical results," not attitudinal or cultural change; (5) have a diminished scope of mass participation in favor of narrow mobilizations of the target population; and (6) utilize extensive propaganda to shape public sentiment, but discourage disruptive mobilizational activities beyond the target population in order to insulate the project from economic production and other reform initiatives.

Several aspects of the family planning campaign illustrate the pattern of institutionalized mobilization. The family planning bureaucracy and delivery network has been strengthened, funding and personnel have increased, routine procedures have been developed to administer the work and coordinate with other relevant departments (for example, public health and civil affairs), and supplemental regulations have been drafted to clarify policy. Family planning work has been thoroughly professionalized; demographers, sociologists, and other social scientists are involved in the policy-making and implementation processes, and fulltime family planning workers are trained and placed at the local level. National meetings are held regularly in order to assess ongoing work. Grassroots cadres have forms, procedures, and timetables for gathering data on local demographic trends. New loopholes in the control system, such as the problem of unmonitored peasants who migrate temporarily to the cities, are closed as new procedures are developed-in this case by requiring local commercial bureaus and offices to withhold enterprise licenses from individuals who violate family planning regulations. 35

None of these developments has obviated the need for mobilizational methods, however. The strict one-child limit has been progressively relaxed since 1984 in order to make the policy "acceptable to the peasants." 36 As a result, rural couples whose first-born is a daughter are automatically eligible for a second child.37 This relaxation has partially accommodated the demand for male offspring that frustrated earlier enforcement efforts, but it has not put an end to peasant resistance. Couples with one son or two daughters often bear additional children; the required four-year interval between the first and second birth is routinely ignored; and village leaders conspire with relatives and friends to conceal "excess" births from higher authorities.

35 De Ming, "China's Population Situation Remains Grim," Liaowang Overseas Edition 17 (April 25, 1988), Io-1 I, in FBIS, May I I, 1988, p. 28.

${ }_{36}^{6}$ China Daily, April 19, I988, p. I.

${ }_{37}$ Zhejiang Ribao, September 27, 1987, in FBIS, October 13, 1987, pp. 31-32; China Daily, July 30, 1987, p. 3; Zhao Yugui, "Zhongshi liudong renkoude jihua shengyu guanli" [Pay attention to the management of family planning work for the floating population], Renkou yu Jingii 2 (1988), 5 . 
Continuing resistance to a one- or two-child limit is not the only motive for mobilization. Because the targeted age cohort is constantly replenishing itself, because today's compliant couples may become tomorrow's problem, and because overworked rural leaders find it convenient to neglect family planning, only periodic mobilization can indoctrinate young couples and emphasize the determination of the state to prevail. Family planning propaganda and education campaigns occur predictably in the summer and winter; the campaigns are coordinated with agricultural slack seasons, the corresponding national work conferences that review local and national statistics, and the Chinese New Year (a time for spousal reunions and marriages). They still require the temporary mobilization of propagandists, family planning workers, and medical personnel for grassroots work. Propaganda activity and intensive indoctrination have ceased to be the centerpiece of the campaign, however. Instead, the focus is on the achievement of practical results by carrying out medical procedures such as sterilizations, abortions, and IUD insertions on the spot. $3^{8}$ For example, in the fall of 1987 Zhejiang Province launched a "family planning publicity and technical service campaign," in which "areas lagging behind" in family planning work were urged to "strive for a marked improvement during the campaign." 39 Similarly, a circular prepared for family planning month in Yunnan (January I987) stressed the need to "mobilize the masses to vigorously and conscientiously implement the measures for birth control and remedial measures" (that is, abortions). $4^{\circ}$

Although national officials like Peng Peiyun, head of the State Family Planning Commission, stressed that cadres "should not neglect regular work and then merely rely on temporary mobilization work," ${ }_{41}$ local enforcement still revolves around centrally disseminated targets and quotas that trigger periodic mobilizations and "shock drives" at the local level. A classic example of this pattern is the May I985 campaign that was waged in a suburban village outside Xiamen municipality, Fujian Province, and reported by Huang Shu-min..$^{22}$ In May 1985 , the village leaders suddenly announced a strict new policy on having a second child and ordered all women of child-bearing age to report for examinations to detect pregnancies. The decision was made summarily and backed up

${ }^{38}$ Zhejiang Ribao, July 25, I986, p. I.

39 Zhejiang Ribao, September 27, 1987, in FBIS, October 13, 1987, 3 I-32.

$4^{\circ}$ Yunnan Provincial Service, January 5, 1987 , in $F B I S$, January 7,1987, p. Q2.

${ }^{41}$ Yang Chaoling and Li Qin, "Peng Peiyun, Minister of the State Family Planning Commission, on China's Family Planning Situation and Policy," Liaowang Overseas Edition I7 (April 1988), 9-1o, in FBIS, May 2, i 988, p. 35.

${ }^{42}$ Huang Shu-min, The Spiral Road: Change in a Chinese Communist Village through the Eyes of a Communist Party Leader (Boulder, CO: Westview Press, 1989), I 75-85. 
by the terse announcement that those who failed to comply would be cut off from village business activities. Despite the reforms, this threat was extremely potent, since village approval for permits and loans smoothed the way for many of the private economic activities that produced the bulk of income for many village households. No educational meetings were held, no propaganda announcements were made. On the appointed day, however, a special work team from the township arrived in the village to consult with the village party secretary and to transport pregnant women to the township hospital. The work team was one of several sent out by the township, each assigned to cover a group of villages.

Although the events in the village were straightforward, they do not reveal how the mobilization process made its way to the village level or explain the timing of the campaign. Media reports from the period reveal that, in standard campaign fashion, the impetus came from higher levels of government. During I 984 and I 985 , most provinces responded to new central guidelines on family planning by adopting new or modified regulations at meetings of their provincial people's congresses. Because 1985 was the final year of the Sixth Five-Year Plan, extra pressure was placed on all provinces and localities to meet the targets of the plan. The approach taken by each province varied, however; the timing tended to coincide with the convening of the provincial people's congress, the official legislative body of the province. In Fujian, the Third Session of the Sixth People's Congress was held in late April and early May, at which time a special forum on family planning was held. According to a radio report on the meeting, the delegates were told that they "must do a good job on work in May and June, a key period on which the success of the population control tasks in the whole year depends." 43 Once this provincial directive was translated into specific quotas for each county and township, it resulted in the deliberate and methodical village-level mobilization.

In 1987 , Sichuan provincial authorities launched a summer "propaganda, inspection and implementation drive"; 44 in Hainan, regional officials organized a springtime "shock drive." Cadres were instructed to

summon up the greatest resolve to organize the family planning shock drive, and achieve unified leadership, arrangements, and action. ... It is necessary to focus on remedial measures regarding pregnancies not covered by the plan, and also do a good job in carrying out ligation surgery after the birth of a second child and inserting an intrauterine device after the birth of a first. 45

${ }^{43}$ Fujian Provincial Service, May 3, I985, in FBIS, May 9, I985, p. OI.

${ }_{44}$ Sichuan Provincial Service, June I I, 1987, in $F B I S$, June I2, I987, p. Q I.

${ }^{45}$ Hainan Island Service, May I, I987, in FBIS, May 4, I987, p. PI. 
Two weeks later, regional officials reported that, between April 27 and May 9, more than 8,700 procedures, including 4,244 tubal ligations, had been performed. ${ }^{6}$ After criticizing areas that were still lagging behind, they called for a "new high tide," and issued specific instructions:

Prior to the end of June, all cities and counties must accomplish over 50 percent of the special annual family planning tasks set by the administrative regional authorities.

Second, in bringing about the high tide ... all cities and counties must regard the task of collecting fees imposed on those who have exceeded the limit to the number of births as an important task, and ensure the implementation of measures for sterilization through the promotion of the task of collecting fees imposed on those who have exceeded the limit to the number of births.

Third, public health departments ... must send a number of medical personnel with high political and professional standards to serve people undergoing sterilization operations. ${ }^{47}$

When Hainan officials met in February 1988 to review the previous year's work and plan for the future, their report captured precisely the effort to fuse regular work with campaign tactics:

We must establish and put on a sound basis family planning laws, rules and regulations, and beef up the family planning organs and personnel. Shock family planning drives must be regularly organized and combined in an organic way, with the emphasis on practical results. $4^{8}$

Weak grassroots organization also makes mobilization a necessity. Professionals and full-time family planning workers may staff family planning organs at or above the county level, and sometimes at the township (previously the commune) level; below the township level, family planning, if done at all, is conducted by party cadres and women's leaders- that is, local political leaders and activists. 49 After I984, when structural reform of the communes was completed, all township governments were supposed to be staffed by a full-time cadre for public health and family planning. In many areas, however, townships have refused to pay such individuals out of collective revenues, but the state has not put them on its payroll either. As a result, many townships have no family planning cadre, or one that is poorly paid..$^{\circ}$ At the village (brigade) and small

${ }^{46}$ Ibid.; Hainan Island Service, May I8, 1987 , in FBIS, May 20, I987, p. P2.

47 Ibid., pp. $\mathrm{P}_{2}-3$.

${ }^{48}$ Hainan Island Service, February I 7, I988, in FBIS, February I 8, I988, p. 2 I.

${ }^{49}$ Henan Nianjian, 1985 [Yearbook of Henan Province, 1985] (1986), 597. By I987, Qinghai Province reported that $30 \%$ of all townships and towns had no family planning organs. Qinghai Provincial Service, February 20, 1987, in FBIS, February 27, 1987, p. T2. See also Liaoning Provincial Service, February 28, 1988, in FBIS, March 3, I988, p. 38.

$5^{\circ}$ Qinghai Provincial Service, February 20, 1987, in FBIS, February 27, 1987, p. T2. See 
group (team) levels, family planning came under the purview of the local women's leader, but team-level cadres slowly disappeared after 1984 and village leaders often refused to employ a family planning cadre, leaving the job of enforcing local birth quotas to unpaid representatives of the Women's Association. Even where cadres are in place, however, many of them are villagers first and cadres second where family planning is concerned. They will respond to signals from higher authorities, but professionalization does not reach into the village. In short, functional specialization deteriorates rapidly at the township level and below, and neither the collective nor the state has the funds to remedy the problem entirely. Instead, family planning associations have been organized down to the village level in the hope that locally mobilized and functionally defined mass organizations will contribute to the stabilization of the work. ${ }^{11}$ Thus, at the grassroots, politically weak, poorly skilled, and underpaid women's leaders, activists, and association members rely on local party mobilization in order to cope with recalcitrant villagers. In 1988 , this dependency on the party apparatus led central leaders specifically to exempt family planning from ongoing efforts to reduce party interference in routine government work..$^{22}$

Finally, although the intensity of family planning propaganda has declined since 1985 , family planning work has constantly been linked to other political, ideological, or morality movements, including party rectification, the antibourgeois liberalization campaign, and the call to build a socialist spiritual civilization. The linkage is designed to reinforce the collective value and larger moral purpose of individual decisions to comply voluntarily with family planning goals, and to associate policy violators with politically suspect, morally bankrupt, or criminally inclined elements.

In sum, implementation of the one-child policy continues to meet the two primary characteristics of a mobilization campaign-organized, routine-altering activity for the purpose of defeating a barrier to socialist development. Since 1984 , however, the predictability, decentralization, and routinization of the mobilization process has transformed the campaign into a mobilizational instrument of some precision. While the Communist Party is unwilling to alienate the critical pro-reform peasant

also Liaoning Provincial Service, February 28, 1988, in FBIS, March 3, i988, p. 38 . In some cases, "family planning cadres" were individuals who held more than one work portfolio simultaneously. See Shuai Zepeng, "Jihua shengyu ganbu duiwude guanli jidai jiaqiang" [Management of family planning cadre ranks in urgent need of strengthening], Renkou Yanjiu 4 (July 1988), 59. Tianjin Ribao, March I3, 1990, in FBIS, April I I, 1990, pp. 45-46.

${ }^{51} F B I S$, February 19, I988, p. 23.

${ }^{52}$ Xinhua, January 20, 1988, in FBIS, January 21, 1988, p. 6. 
constituency by demanding strict enforcement of a one-child limit, it is equally unwilling to channel more state funds into the development of a rural family planning bureaucracy or to let resistance to birth control undermine its economic goals. The routine bureaucratic process has therefore been joined to the party's grassroots mobilizational tradition to yield a specific form of postrevolutionary mobilization. This hybrid is not simply a halfway measure between the artificially constructed polarities of revolutionary mobilization and rational-legal forms of enforcement, however. Instead, it is a new variation on the single political theme of Communist Party rule in China. The context for campaign implementation has changed, but mobilizational impulses and the institutional arrangements that produce them have endured.

\section{The Limits of Institutionalized Mobilization}

By early i 990 , it was clear that China's family planning program was in jeopardy. The State Statistical Bureau reported steady population growth rates of about I.4 percent between 1987 and I989-rates higher than planned, but within an acceptable range. Surveys conducted under the auspices of the State Family Planning Commission, however, were showing growth rates as high as I.6 percent; by January i99o Peng Peiyun, the head of the commission, confirmed the existence of a gap of 30 percent between the official figures and the estimates of the commission. ${ }^{53}$ Clearly, the state's efforts to achieve an average fertility level of about $\mathrm{I} .7$ children per couple were failing.

At first glance, this failure may appear to confirm Lowenthal's thesis. One might argue that the general trend in China is toward demobilization, and that the lingering presence of the one-child campaign reflects nothing more than the extraordinary nature of China's population dilemma. The regime's inability to sustain effective mobilizational efforts for more than a few years after the postrevolutionary transition merely confirms the long-term causal relationship between the modernization process and demobilization.

The flaw in this argument is that the failed effort cannot be equated with the end of mobilizational politics. The overall success or failure of a campaign never provided grounds for bringing the mobilizational character of the Maoist regime into question. Mao's two most famous efforts, the Great Leap Forward and the Cultural Revolution, were both spectacular failures if judged by his own initial goals. The Great Leap

53 Qi Bangmi, “The Alarm Bell of Population Tolls Again," Ban Yue Tan 23 (December I988), I5-16, in FBIS, January 18, 1989, p. 25; Xinhua, December 13, 1989, in FBIS, January 5 , 1989 , p. 5 . 
did not boost agricultural yields or accelerate China's march to communism, and the Cultural Revolution did not prevent the routinization of party rule. Yet the mass campaign was a defining characteristic of the Maoist period. In the post-Mao era, rising birth rates alone do not imply that campaigns are no longer employed. Campaigns continue to be the most effective means by which party leaders concentrate effort on specific tasks and overcome bureaucratic inertia and grassroots resistance. In addition, they fill an important gap in the state's capacities below the county level by prompting township- and village-level cadres to behave in ways that reflect the priorities of their superiors. By setting the goals and the time frame for achieving specific tasks, and by linking cadre evaluations to the fulfillment of those tasks, the party can increase the probability of effective grassroots implementation.

Several other factors provide a better explanation for the failure of institutionalized mobilization to achieve the ambitious goals of the central elite. To begin with, the goals themselves remain extremely ambitious, despite relaxations in the one-child rule. According to current policy, all urban couples are limited to one child, with very few exceptions. In the countryside, all couples whose first child is a girl are now eligible to have a second child after an interval of about four years; the same goes for couples who fit a variety of other categories (for example, those whose first child is seriously handicapped, or a husband who breaks tradition by moving into his wife's family home). No one is eligible for a third child, with the exception of certain small nationality populations living in sparsely populated areas. These guidelines may appear lenient by the impossibly strict rules of the early 1980 , but in China's agricultural society they are considered extremely strict and are difficult to enforce, even with campaign methods.

Moreover, for mobilization to be successfully deployed, at least one of three prerequisites must be met. The first concerns incentives. In earlier efforts to engineer change in the countryside, success depended on being able to offer material as well as normative incentives to a mobilizable constituency. ${ }^{54}$ Great efforts were made to do just that in the early i 980 , when one-child couples received preferential health care, infant and child subsidies, extra plots of land, and other material rewards.55 By i 984 , however, as the one-child policy settled into a fundamental state policy, the rationale for special rewards for compliance began to erode, as did

${ }^{54}$ Dittmer (fn. I), 39-43 and 237-38; Vivienne Shue, Peasant China in Transition: The Dynamics of Development toward Socialism, 1949-1956 (Berkeley: University of California Press, I980), 326-27.

55 White (fn. 23), 284-317. 
the local resources to provide them. In addition, pressures to reduce the expenses of township government led to cuts in family planning subsidies and bonuses. ${ }^{6}$ As a result, by the mid-1980s cadres and bureaucrats urged family planning on grounds of delayed material gratification, a line that did little to offset preferences for multiple sons as the path to short-term happiness and long-term wealth and security.

Second, sustained and successful mobilization requires organizational stability. 57 Where turnover among local leaders or a target population is high, patterns of mobilization, study, and enforcement are constantly disrupted by personnel change. Although China's rural leadership has remained relatively stable, organizational changes, retirements, entrepreneurial opportunities, and elections have all contributed to a changing composition of the grassroots leadership. More importantly, however, the rural population - for the first time since the i95os-now enjoys opportunities for mobility that complicate efforts to enforce family planning through either routine work or mobilization. The reported childbearing explosion among the "floating population" of fifty million has become the biggest headache for family planning officials, who refer to this group as an "excess birth guerrilla corps" and "excess birth floating villages." 58 The proposed solution-demanding that the urban commerce bureaus verify compliance with family planning before issuing local commercial licenses to migrant peasants-is no help, since commerce bureau officials have neither the time, inclination, or incentive to become adjunct family planning officials. ${ }^{59}$

Third, and most importantly, in the absence of compelling material rewards and organizational stability, mobilization requires a disciplined organization for enforcement-precisely the area in which communist parties traditionally excel. In this case, however, many cadres (native villagers themselves) have personally opposed and violated the one-child policy from the start. Beijing's disavowal of coercion and rigidly uniform implementation has simply given them greater leeway to interpret guidelines in ways that suit local preferences. Moreover, despite periodic nation-wide or localized mobilizations, the relatively lax political environment and stress on economic performance led many to report false statistics for family planning work in order to increase bonuses, avoid

${ }^{56}$ Renmin Ribao, June I 2, I984, carries the original text of Central Document I (1984). For a translation, see China Quarterly Iо I (March i985), I32-42.

57 Walder (fn. 9), I I 4-20.

${ }^{58}$ Guo Xiao, “The 'Population Explosion' Is Drawing Near," Jingji Ribao, January ı, 1989, in FBIS, February 3, I989, p. 5 I.

${ }_{59}$ China Daily, July 30, 1987, p. 3; Yunnan Provincial Service, January 3, 1988, in FBIS, January 5 , I 988 , p. 44; Xinhua, January 26,1988 , in FBIS, January 28 , I988, pp. I6-1 7 ; Renmin Ribao, June 4, 1985, p. 3 . 
sanctions, meet the terms of their responsibility contracts, and reduce per capita tax levies. ${ }^{60}$ Other cadres devised a middle course that linked nominal enforcement to personal and collective self-interest. Rather than try to prevent excess births, they used them as a fundraising tool, collecting penalties for infractions and investing them in local projects. In one report, a village party secretary was quoted as saying that in "four or five days' time," the village had collected ro,ooo yuan, "just enough to pave a village road." The reporter condemned this practice of encouraging "fundraising births" as an "evil embryo" (guaitai) that should be terminated, but the problem was not simply one of cadre deviance at the village level. In some areas, the money-starved family planning bureaucracy was dependent on the collection of fines to pay salaries and bonuses. ${ }^{61}$ This preoccupation with fundraising went even further: mobilization campaigns intended to prevent excess births were perverted into fundraising campaigns, with local cadres assigned targets for the collection of fines, and with campaigns timed to occur when peasants were flush with cash. ${ }^{62}$ Paradoxically, campaigns thus became the vehicle by which routine bureaucratic work could be sustained, giving the bureaucrats themselves a direct interest in perpetuating mobilizational methods.

In short, during the i 980 s the requirements for effective mobilization were undermined by the successful implementation of other elite goals. Deepening problems with routine implementation and enforcement, however, elicited new demands for mobilization from unusual sources. In family planning, these demands did not come from conservatives threatened by the reforms, but from reform-minded experts and observers who feared the economic impact of population growth.

In 1988 and 1989 their anxieties broke to the surface. The revelation, in late 1988 , that the 1987 birth rate was significantly higher than originally reported by the State Statistical Bureau, that third or additional births continued to account for as much as iz percent of annual births, and that urban couples were also pushing for additional births, caused growing apprehension over inadequate birth control efforts and the potential "tragedy" of failing to control population growth. ${ }^{6}$ In Hebei,

${ }^{60} \mathrm{Qu}$ Yibin, "Woguo renkou chushenglu mingxian huishengde yuanyin ji duice tantao," [Reasons for our country's obvious increase in birth rate and inquiry into countermeasures], Renkou Yanjiu 2 (March 1988), pp. 54-55; Zhong Cheng, "Delegates and Members Show Concern for Family Planning," Zhongguo Xinwen She, April i I, 1988, in FBIS, April I3, I988, p. 33 .

61 Jiang Su and Yang Shounian, “'Jizi shengyu' buzu qu” [Do not permit the pursuit of 'fundraising births'], Nongcun Gongzuo Tongxun 4 (I988), 25.

${ }^{62}$ Interview with former township-level family planning cadre, March I, I990.

${ }_{63}$ Henan Provincial Service, January 21, 1989, in FBIS, January 25, I989, p. 53. 
these concerns led to the creation of an extraordinary coordinating body, the "family planning leading small group," to increase province-wide attention to family planning. ${ }^{64}$ Such groups, which were pervasive in the I 970 s and early I980s, had been replaced in the mid-i 980 os by regular state organs and local family planning commissions. What was most telling, however, was an escalating debate between what might be called the state family planning establishment, on the one hand, and opposition professionals, social scientists, and party officials, on the other. The latter group argued that relaxation of the one-child policy was a mistake, and held policy makers and "personnel changes" responsible.65 After this charge appeared in Guangming Ribao in March I988, officials of the State Family Planning Commission felt obliged to respond at their national meeting shortly thereafter. China Daily, for example, reported:

The policy that allows rural couples with only one daughter to have one more child after a certain period has proved reasonable and is not the reason for the rapid growth of China's population in recent years, it was agreed at a national meeting of the State Family Planning Commission. ... ${ }^{66}$

Around the same time, an article in Renmin Ribao pointed out that the desire for a rapid push for zero or negative population growth must be carefully balanced against the problem of an aging population. ${ }^{67}$

The debate intensified in 1989, with Jingii Ribao picking up the call for a stricter birth control policy. Two articles, the first on January io and the second on January 24, stressed the impending population crises and asked, "How many centuries must it take before people can be awakened?" 68 The second, arguing that a "human wave is washing over China," pointed to the I980 Marriage Law, the stimulating effect of the agricultural responsibility system on rural child-bearing preferences, and the relaxation of policy after 1984 as three key "policy faults." 69 It is the final paragraphs, however, that reveal the changed rationale for mobilization. Dismissing "gloomy and feeble propaganda and education" as useless in an environment where "people no longer fear punishment," the author blasted the family planning bureaucracy and "policy-makers" for their timidity; he concluded:

${ }^{64}$ Hebei Ribao, September 16, 1988, p. I, in FBIS, October 1 2, 1988, p. 64.

${ }^{65}$ Liu Jingzhi, "Experts Concerned Are Not Optimistic about China's Population Situation, and Think that Interference by Officials Is an Important Reason Why Birth Rate Has Risen Again," Guangming Ribao, March 6, I988, p. 2., in FBIS, March 18, I988, pp. 14-15.

${ }^{66}$ China Daily, April 19, I988, p. I.

${ }_{7} 7 \mathrm{Wu}$ Canping and Du Yajun, "Several Questions on the Chinese Population," April ${ }_{15}$, 1988, in FBIS, April 19, 1988, pp. 48-49.

${ }^{68}$ The quote is from Xie Zhenjiang, "There Is No Route of Retreat," Jingji Ribao, January 24, I989, in FBIS, February 15, 1989, p. 35; see also Guo Xiao (fn. 58), 50-52.

${ }_{69} \mathrm{Xie}$ (fn. 68), 36-37. 
As happy peace must be built on the foundation of powerful military strength, so are the people's voluntary and self-conscious actions to be formed on the basis of the legal and compulsory standard. We should justly and forcefully say that we must punish those who have turned a deaf ear to dissuasion from having additional children and from unscrupulously having additional children and that suitable coercion and control should be implemented in China's family planning.

... Only if the country adopts effective and compulsory policies and at the same time, carries out propaganda and education, can the consciousness of the society be aroused. If we do not understand this problem and change the current situation soon, when we wake up in a number of years, we shall find that it will be too late..$^{\circ}$

This message is a plea for effective mobilization. Despite its open advocacy of the use of coercion and compulsion, however, it is not a plea to re-create the disruptive mass campaign formula of the Maoist past. On the contrary, it is notable for its emphasis on enforcement of the "legal and compulsory standard," the adoption of "effective and compulsory policies," and for its denigration of "gloomy and feeble propaganda and education"-language out of character with the mobilization politics of the Maoist period. Instead of a disruptive mass campaign, the author calls for a targeted effort to enforce regulations already in place, and to create new, more effective ones where necessary. In short, it is a call for party mobilization to implement social policy by all necessary means, including force, but not for mobilization on a mass scale.

\section{Sources of Mobilization in Chinese Politics}

In contrast to the hypotheses of Lowenthal and Jowitt, I have argued that China in its postrevolutionary phase has not abandoned mobilizational methods to achieve party-defined goals. That is not to say that China remains a mobilization regime, but rather that mobilizational methods have been recast in ways that make them useful to the reformist elite. The result has been a variant form of campaign politics which I call institutionalized mobilization. A final objection that might be raised to this analysis is that the case of the one-child policy is unique, and therefore cannot be fairly projected on China's postrevolutionary politics in general. Since there is no denying that China's demographic dilemma is unique, the question is whether or not it has provoked a unique political solution.

The political trajectory of the one-child policy has been anything but exceptional. On the contrary, it has accurately mirrored the foremost 
political dilemma of the Deng regime in the r 980 - engineering rapid socioeconomic modernization within prescribed Leninist boundaries while relaxing tight political controls. Although the death of Mao in 1976 paved the way for the abandonment of the Maoist path to development and his radical revolutionary vision, Deng Xiaoping's alternative vision, which began to crystallize in 1978 , was also radical and ambitious. Unlike Khrushchev, Deng was prepared to do more than merely repudiate the political excesses of his famous predecessor. He embarked on a modernization strategy that swiftly and fundamentally reversed the deeply rooted Maoist approach. That reversal demanded a deradicalized political environment. But the degree of societal adjustment required for reform, the formidable political opposition to be overcome, and the scope of Deng's reform goals called for the skillful utilization of a familiar political process - mobilization of both party and society to break out of old political and economic routines in favor of new ones.

This effort to reorder an existing socialist society began with a denunciation of political campaigns and mass movements; but it was followed by a spate of dramatic reform initiatives that demanded full mobilization of the party machine. In the countryside, for example, there were tree planting campaigns, electoral reform campaigns, drives to reduce the collective burdens on peasants, the drive to build a socialist spiritual civilization, and, of course, the drive to decollectivize universally and to introduce household contracting. None of these mobilization drives resembled the radical mass campaigns of the Maoist era, and local party cadres sometimes lagged behind enthusiastic peasants. Nevertheless, the basic process of pushing through comprehensive reforms between 1978 and 1983 followed the Leninist, or "engineering," approach to social change-mobilization of the party and mass organizations to take the lead in implementation, and skillful and massive use of the propaganda apparatus to build support for the reformist line and to isolate political opponents.

This brings into question the presumption of a static definition of mobilization as a process of calculated disruption in pursuit of utopian ends. The purpose of mobilization during the stage of socialist transformation was the disruption of bourgeois social arrangements and routines in favor of new socialist arrangements; ${ }^{71}$ in Deng Xiaoping's postrevolutionary regime, the purpose of mobilization is to ensure the responsiveness of local cadres to higher-level initiatives, and to gain societal compliance with party efforts to reorder the established institutions and routines of socialism. The party remains the instrument of mobilization and di- 
rected change, but an atmosphere of orderly determination replaces that of "crisis and attack." 72 Mobilization has ceased to be synonymous with permanent revolution, but it remains an essential tool for implementing far-reaching reform while enforcing political orthodoxy. Crises of political power, like the Beijing Spring of 1989 , may trigger a reversion to all or most of the revolutionary campaign methods of the past, but mobilizational methods also play important, if more subdued, roles in accomplishing ordinary policy goals on a national or local scale.

The party's continued reliance on mobilizational methods derives from the lingering memory of the institutionalized role that campaigns played during the Maoist era and the defining tendency of Leninist parties to rely on directed mobilization as the basic approach to political change and control. Beyond these institutional bases, however, the longevity of mobilization in China is rooted in structural and political factors.

A chronic and enduring problem in China's vast countryside is that the elite's demands outstrip regular bureaucratic capacities to meet them. In China, all bureaucratic trails lead to township and village leaders. Unlike the county-level bureaucratic apparatus, however, township governments lack the manpower and the skills to routinize party and government work effectively on a consistent basis. At the village level, leaders cease to be full-time employees of the state, and their lack of mobility at this level makes them permanent fixtures in their native communities. Although this organizational arrangement was essential to the transformation of rural China and the consolidation of the CCP's rule, the dual face of village leaders has always posed obstacles to the implementation of central policies that run counter to village interests. Although the leadership routinely tolerated a degree of slippage and corruption at the village level, its single most effective device for containing that slippage was the mass campaign. Social transformation was therefore only one of the motivations for the mobilizational approach to policy implementation. The other was the prevention of organizational decay at the grassroots.

With this tradition of rural mobilization so deeply rooted in the collective memory and so crucial to the maintenance of a disciplined party organization (attributes that separate the Chinese experience sharply from that of the Soviet Union), the formal repudiation of political campaigns did little to alter the behavioral response of local cadres who had a limited repertoire of leadership methods. In the short run, patterns established over decades ensured that party cadres remained highly sensitive to mobilizational cues from the center-so much so that they were

${ }^{72}$ David E. Apter, The Politics of Modernization (Chicago: University of Chicago Press, I965), 360. 
still susceptible to the political sins of overzealousness and "commandism" (exercising arbitrary and dictatorial rule).73

Over time, however, the decentralization and diversification of power resulting from successful reform eroded both the fear of retribution and the promise of meaningful reward necessary to mobilize society effectively, and altered the relationship of the party center to the far-flung party rank and file. As local cadres were rewarded more for economic entrepreneurship than for political discipline, and as the demands of newly empowered provincial or county officials took precedence over Beijing's instructions, old forms of political deviance gave way to new ones. "Coercion and commandism" (qiangpo mingling) in family planning yielded to neglect and to falsification of records; more broadly, economic commandism and leftism were replaced by corruption and bourgeois liberalization as the most dangerous forms of political deviance.

Yet mobilization campaigns did not disappear. Instead, they were utilized by central, provincial, and even county officials as a routine method for getting things done. ${ }^{74}$ Moreover, as fiscal austerity started to impede government work in the late 1980 , mobilization became a convenient bureaucratic tool for overriding fiscal constraints by placing temporary political pressure on reluctant cadres.

Mobilization of some sort may not necessarily remain a permanent feature of Chinese politics. The perpetuation of variant forms of mobilization in postrevolutionary China, however, does bring into question the dichotomous phasing of communist state evolution implied in earlier models. The campaign method, which implies a mobilizational override of routine bureaucratic procedure, is an institutional and procedural correlate of Communist Party rule in China. Rather than dying away in the postrevolutionary era in favor of routinized, Weberian bureaucratism, institutionalized forms of mobilization have found common ground with bureaucratic process. ${ }^{75}$ Regardless of official rhetoric, neither modernization writ large nor the death of Deng Xiaoping and other revolutionary elders is therefore likely to extinguish this form of campaign. That would require a more fundamental rearrangement of the structure of power than China's Leninist rulers have been willing to permit.

${ }_{73}$ Stuart R. Schram, Ideology and Policy in China since the Third Plenum, 1978-84, Research Notes and Studies No. 6 (London: Contemporary China Institute, School of Oriental and African Studies, 1984).

${ }^{74}$ For example, Michel Oksenberg reports that campaigns were utilized by county officials in Zouping county, Shandong Province. See his "Preliminary Impressions of Zouping County Level Government" (Paper presented at the Association for Asian Studies Annual Conference, Chicago, April 6-9, 1990).

75 The implications for a single pattern of political authority and a non-Weberian form of bureaucratic evolution parallel the conclusions of Walder (fn. 9), chaps. 7 and 8. 